\title{
BALLISTOCARDIOGRAPHIC STUDY OF CHANGES IN CARDIAC OUTPUT DUE TO RESPIRATION ${ }^{1}$
}

\author{
By A. B. OTIS, H. RAHN, M. BRONTMAN, L. J. MULliNS, ANd W. O. FENN \\ (From the Department of Physiology, School of Medicine and Dentistry, University of \\ Rochester, Rochester, New York)
}

(Received for publication December 26, 1945)

As a measure of cardiac output the ballistocardiograph leaves much to be desired and the results obtained with this instrument must be accepted with proper caution (Hamilton (1)). Changes in the record can be produced, however, by small variations in experimental conditions which appear to be best interpreted as changes in cardiac output and it seems likely that the method is reliable for relative values when controls are available on the same subject under normal conditions. All the experiments reported in this paper were carried out in this way with a normal record followed immediately by an experimental record on the same subject under altered respiratory conditions; the changes observed are tentatively considered to be due to changes in cardiac output.

The respiratory conditions which we have studied are (1) continuous elevated pulmonary pressure, (2) intermittently elevated pulmonary pressure, (3) voluntary overventilation, (4) artificially increased dead space, (5) increased alveolar oxygen tension by inhalation of pure oxygen.

\section{METHOD}

The ballistocardiograph was designed for us by Dr. H. A. Blair of this laboratory in 1942 . The subject reclines on a wooden "bed" made of plywood mounted by means of springs on a massive and rigidly built wooden table. The mountings consist of four straps of spring steel located approximately under each of the four corners of the bed like short legs. These steel straps are 1/16 inch thick and 1 inch wide and 1.75 inches long. They stand vertically and support the weight of the bed. The flat sides face toward the head and foot of the bed so that the bed vibrates longitudinally and the straps bend slightly although imperceptibly. The natural period of vibration of the table is varied by varying the length of the straps. This dimension was so adjusted that the bed made 10 complete vibrations per second with a dead load on the bed of $150 \mathrm{lbs}$. Movements of the bed were recorded op-

1 Work done under contract, recommended by the Committee on Medical Research, between the Office of Scientific Research and Development and the University of Rochester. tically by means of a "phoneloscope," made by the Capitol Instrument Co. of Washington, D. C. This is an instrument designed originally to record sound waves and consists of a steel diaphragm, movements of which rotate a small shaft on which a mirror is mounted. Movements of this mirror were recorded optically with an electrocardiographic camera with a magnification of the movement of the diaphragm of about 8000 times. The sensitivity of the apparatus was $0.6 \mathrm{~cm}$. per 100 grams. The diaphragm was connected to the bed of the ballistocardiograph by means of a fine wire under tension of about 100 grams.

In some of our studies we used a vertical ballistocardiograph. This was constructed on the same principle, except that the bed was oriented at an angle of about 15 degrees with the vertical. Arrangements were made so that the subject could either stand on this tilted bed, leaning back against it, or he could sit on a seat which could be attached to the bed when desired. Movements were recorded with a phoneloscope as before. The sensitivity was $0.3 \mathrm{~cm}$. per 100 grams and the frequency was 11 per second. In common with the experience of others, we found the vertical ballistocardiograph much more susceptible to extraneous vibrations and the records much less readable.

Stroke volumes were computed from measurements of the wave heights using two of the formulae of Starr et al. (2).

and

$$
\begin{aligned}
& S V=K \sqrt{(3 I+2 J) A C^{3 / 2}} \\
& S V=K \sqrt{J A C^{3 / 2} .}
\end{aligned}
$$

The latter formula was used only in the first series of measurements on the horizontal apparatus.

In these equations $K=$ constant for the apparatus; $I=$ height in $\mathrm{mm}$. of the $I$ wave (first downward deflection); $J=$ height in $\mathrm{mm}$. of the $J$ wave (subsequent upward
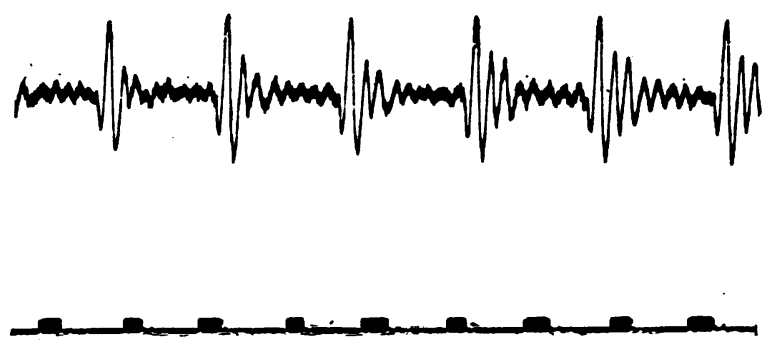

Fig. 1. Sample Record During Normal Breathing Time in half seconds 


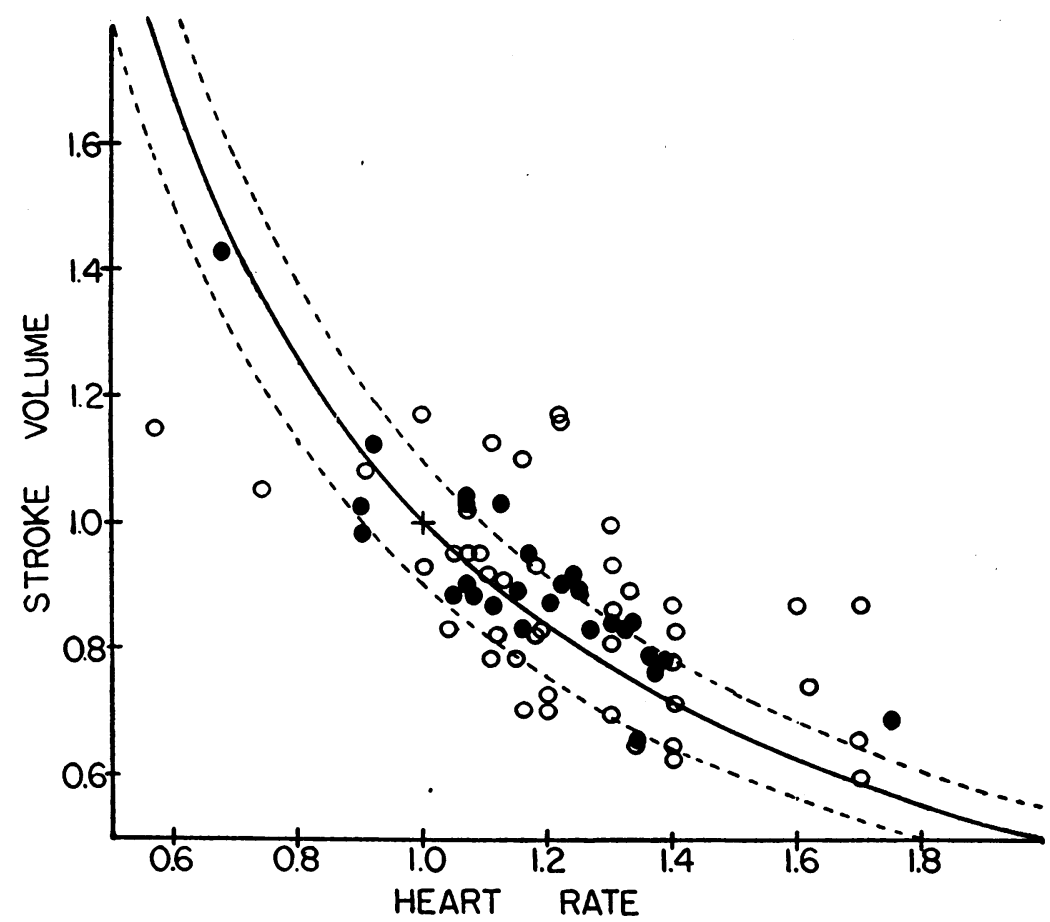

Fig. 2. The Effect of Breathing Against Positive Pressure on the Stroke Volume, and Heart Rate

Each point represents a comparison between normal and experimental conditions, heart rate and stroke volume being expressed each as a fraction of the normal value taken as 1.0 . The normal is therefore represented by the cross $(+)$ at point $1.0,1.0$ on the diagram, and all the points are relative experimental values. The solid line is a rectangular hyperbola passing through the cross and indicating points where the product of heart rate and stroke volume, or the cardiac output, is constant and normal. Broken lines represent cardiac output 10 per cent above (on the right) or below (on the left ) normal. Open circles = horizontal, and closed circles $=$ vertical ballistocardiograph. Note that the points lie in general to the right of the cross (increased heart rate) but below (decreased stroke) so that they scatter more or less uniformly both above and below the solid curve. This indicates no average change in cardiac output.

deflection) ; $A=$ aortic cross section in sq. cm. ; $C=$ duration in seconds of one cardiac cycle.

In most cases we made no effort to calculate the cardiac output or stroke volume in absolute units, but determined only relative magnitudes.

A typical normal record is shown in Figure 1, demonstrating that the tracings are clear and easily measured and in general similar to those published by Starr et al. (2).

\section{RESULTS}

\section{(1) Changes in intrapulmonary pressure}

In this series of experiments positive pressure was applied to the lungs either through a mouth piece for short periods or for longer periods through a helmet which covered the whole head and which was sealed around the neck with a Drinker respirator type of sponge rubber collar. The subjects breathed air of which the pressure was controlled between 25 and $30 \mathrm{~cm} . \mathrm{H}_{2} \mathrm{O}$ by a limit valve, and the flow was sufficient to prevent the accumulation of carbon dioxide. The mouthpiece could not be used for long periods on account of the resulting fatigue of the cheek muscles. In the sitting position we have 14 experiments on 8 different male subjects; in the supine position, 17 experiments on 14 subjects. The results may conveniently be summarized in Figure 2, in which the ordinates represent stroke volumes as a fraction of the nor- 
mal stroke volume, and abscissae represent heart rates expressed as a fraction of the normal heart rate. In such a graph all points with a normal cardiac output of 1.0 should lie along a rectangular hyperbola passing through the point 1,1 , marked by a cross. The dotted lines indicate cardiac outputs 10 per cent greater or less than this normal. Values in the sitting position are indicated by solid circles and those in the supine position by open circles. It is evident from this chart that in most cases there is little change in cardiac output, although some subjects show an increase and some a decrease. However, there is a well marked tendency for the stroke volume to decrease and the heart rate to increase enough to compensate. In a few cases the heart rate decreased and the stroke volume increased. The two points showing the greatest decrease in cardiac output are on the same subject, a 19-year-old girl whose heart failed to accelerate enough to maintain the cardiac output even though the stroke volume was above normal.

The grand average of all the figures shows an increase of heart rate of 1.18 times while the stroke volume decreased to 0.89 of the normal. The product of these two gives a cardiac output 1.05 times the normal. From the same experiments average values, including both sitting and supine figures, have also been obtained at different times from 15 seconds to 10 minutes after the beginning of pressure breathing, but no consistent change with time could be discerned. The heart rapidly adjusts itself to the unusual conditions and maintains this adjustment with a fairly constant value. On the average, the cardiac output, so measured, does not differ significantly from the normal at pressures up to $30 \mathrm{~cm} . \mathrm{H}_{2} \mathrm{O}$, although there are certain individuals at certain times who do show a decrease.

Higher pressures for short periods of time have been tested in two subjects who were asked to exert voluntary pressure against a mercury manometer as in the Flack test for circulatory efficiency (3) or the test outlined by Bürger (4). In these cases the stroke volume did diminish, but the heart rate increased enough to more than compensate so that in one subject at $50 \mathrm{~mm}$. $\mathrm{Hg}$. the cardiac output was 158 per cent of normal, while in the other at $40 \mathrm{~mm}$. Hg. it was 119 per cent of normal.

For purposes of comparison, a few experiments have been carried out on subjects breathing under conditions of negative pulmonary pressures of $-30 \mathrm{~cm} . \mathrm{H}_{2} \mathrm{O}$. Under these conditions also no significant change in cardiac output was found. For 12 cases for periods up to 4 minutes the average values relative to the normal were: stroke volume, 1.0, heart rate, 1.1, cardiac output 1.1.

It should be pointed out that all these experiments were carried out on untrained subjects, largely medical students. The application of positive pulmonary pressure by mouthpiece becomes quite uncomfortable in a very short time and application of pressure via a helmet is no more reassuring to the uninitiated subject. The average time at which these records were taken is less than 3 minutes and one-third of the records were taken less than a minute after applying pressure. In view of the necessary anxiety and short period for adjustment the quantitative results must be accepted with some reservations.

Consequently, another series was obtained on 6 subjects who had had previous experience with pressure breathing in connection with other experiments. Ample time was allowed for these men to adjust themselves to the positive pressure which was administered through a mouthpiece, mask or helmet, and records were taken 10 to 40 minutes later. The results are shown in Table $I$, all values being expressed in percentage of normal. The results were consistent in showing an increase in heart rate, decrease in stroke volume, a decrease in cardiac output and pulse pressure

TABLE I

Effect of positive pulmonary pressure of $30 \mathrm{~cm} . \mathrm{H}_{2} \mathrm{O}$

\begin{tabular}{|c|c|c|c|c|c|c|}
\hline$\underset{\text { ject }}{\text { Sub- }}$ & $\begin{array}{c}\text { Heart } \\
\text { rate }\end{array}$ & $\begin{array}{c}\text { Stroke } \\
\text { vol. }\end{array}$ & $\begin{array}{l}\text { Cardiac } \\
\text { output }\end{array}$ & $\begin{array}{l}\text { Systolic } \\
\text { pressure }\end{array}$ & $\begin{array}{c}\text { Diastolic } \\
\text { pressure }\end{array}$ & $\begin{array}{c}\text { Pulse } \\
\text { pressure }\end{array}$ \\
\hline $\begin{array}{l}\text { RD } \\
\text { PB } \\
\text { WF } \\
\text { PS } \\
\text { AO } \\
\text { AC* }^{*}\end{array}$ & $\begin{array}{c}\text { per cent } \\
115 \\
113 \\
111 \\
115 \\
111 \\
122\end{array}$ & $\begin{array}{c}\text { per cent } \\
71 \\
76 \\
86 \\
65 \\
83 \\
65\end{array}$ & $\begin{array}{c}\text { per cent } \\
82 \\
85 \\
98 \\
75 \\
94 \\
79\end{array}$ & $\begin{array}{c}\text { per cent } \\
107 \\
108 \\
104 \\
100 \\
106\end{array}$ & $\begin{array}{c}\text { per cent } \\
113 \\
120 \\
109 \\
110 \\
115\end{array}$ & $\begin{array}{c}\text { per cent } \\
98 \\
84 \\
96 \\
85 \\
91\end{array}$ \\
\hline $\begin{array}{l}\text { Aver- } \\
\text { age }\end{array}$ & 115 & 74 & 86 & 105 & 113 & 91 \\
\hline
\end{tabular}

* These results are averages of many experiments on a single subject with $30 \mathrm{~cm}$. $\mathrm{H}_{2} \mathrm{O}$ applied in different ways as follows: 7 experiments using an aviation mask, 6 experiments using a helmet, 4 experiments with a mask and a pneumatic vest (Mae West) for the application of counter pressure to the chest, 12 experiments with a helmet and vest and 1 experiment using a mouth piece.

All quantities in percentage of normal. 
TABLE II

Effect of artificially forced respiration (Pneumolator) on the cardiac output.

\begin{tabular}{c|c|c|c}
\hline \hline Subject & $\begin{array}{c}\text { Heart } \\
\text { rate }\end{array}$ & $\begin{array}{c}\text { Stroke } \\
\text { volume }\end{array}$ & $\begin{array}{c}\text { Cardiac } \\
\text { output }\end{array}$ \\
\cline { 2 - 3 } RD & per cent & per cent & per cent \\
HR & 89 & 102 & 90 \\
AH & 112 & 77 & 86 \\
AO & 93 & 102 & 95 \\
Av. of 6* & 78 & 93 & 72 \\
Grand Av. & 96 & 90 & 85 \\
\hline
\end{tabular}

* Individual data on these 6 subjects are presented in Table III. The peak pressure on the pneumolator was 20 to $25 \mathrm{~cm} . \mathrm{H}_{2} \mathrm{O}$, frequency 7 to 9 per minute.

All values in percentage of normal.

but an increase in both systolic and diastolic pressure.

The last line in Table I summarizes a number of experiments on one subject (A.C.) who breathed against $30 \mathrm{~cm} . \mathrm{H}_{2} \mathrm{O}$ positive pressure applied with a mask or with a helmet, and with and without counter-pressure from a pneumatic vest. Only average figures of all the experiments are given because the variations in the method of application of the pressure made no difference. All the experiments were similar qualitatively and showed on the average a 14 per cent decrease of the cardiac output. This figure approaches the results of Richards (5) obtained by the direct Fick method on 4 patients breathing $27 \mathrm{~cm} . \mathrm{H}_{2} \mathrm{O}$.

\section{(2) Effects of intermittently elevated pressure with the pneumolator}

Some further experiments were tried with intermittent pressure breathing or artificially forced respiration. For this purpose we used an apparatus built by the General Electric X-ray Corporation called a pneumolator. This instrument supplies oxygen or air to a mask which is inflated along with the lungs until a critical pressure is reached. At this point the inflow of oxygen automatically stops and an expiratory port is opened so that the pressure can slowly fall to zero at a rate which can be controlled by a variable gate. The value of the peak pressure can be controlled for each experiment. As soon as the pressure reaches zero the expiratory port is closed and inflow starts again. The mean pressure in the lungs during a cycle is about 40 per cent of the peak pressure, so this is a form of pressure breathing. Since, however, the pressure is higher in inspiration than in expiration, the process tends to increase the depth of respiration and lowers the alveolar carbon dioxide tension. Breathing through this apparatus is easier than against a continuous pressure, but it is insidious because it is likely to lead to acapnia.

The results obtained with this type of breathing are shown in Table II. The average stroke volume is 91 per cent of normal with a mean pulmonary pressure of 8 to $10 \mathrm{~cm} . \mathrm{H}_{2} \mathrm{O}$. With continuous pressure breathing the stroke volume was decreased to 74 per cent of normal with a mean pulmonary pressure of $30 \mathrm{~cm}$. $\mathrm{H}_{2} \mathrm{O}$. It may be concluded, therefore, that the stroke volume is decreased in both cases in proportion to the mean pressure.

The data of Table II (and Table III) show that 6 out of 10 subjects breathing with the pneumolator had decreased heart rates, the average being 95 per cent of normal. This result contrasts sharply with the figures in Table I where all the subjects uniformly showed increased rates of 11 to 22 per cent over the normal. Largely due to this difference in the reflex response of the heart, the use of the pneumolator results uniformly in a decreased cardiac output averaging 85 per cent of normal.

The reason for the difference in heart rate with the two kinds of pressure breathing is not obvious, but it might possibly be attributed to the greater muscular effort involved when the pressure continues during the expiratory phase.

Brief mention should be made of some other experiments which were undertaken with the idea that the effects of pressure breathing might be artefacts due merely to the change in the degree of inflation of the chest. With a larger chest it was thought that the impacts from the heart might be less well transmitted to the body as a whole. In these experiments the subject held his breath with the glottis open at different degrees of inspiration and expiration while records were taken on the ballistocardiograph. The results showed in general a decreased heart rate at the higher degrees of inspiration in agreement with the findings of Lewis, Lewis, and Hall (6), and vice versa for expiration, but no significant change in the stroke volume. It is perhaps significant that the stroke 
TABLE IIT

Effect on cardiac output of preumolator (Pneu) and voluntary hyperventilation $(V H V)$ at the same alveolar $\mathrm{pCO}_{2}$

\begin{tabular}{|c|c|c|c|c|c|c|c|c|c|c|}
\hline \multirow{2}{*}{ Subject } & \multicolumn{3}{|c|}{ Heart rate } & \multicolumn{2}{|c|}{ Stroke volume } & \multicolumn{2}{|c|}{ Cardiac output } & \multicolumn{3}{|c|}{ Alveolar pCO, } \\
\hline & Normal & Pneu & VHV & Pneu & VHV & Pneu & VHV & Normal & Pneu & VHV \\
\hline M.E. & $\begin{array}{c}\text { beals per } \\
\text { min. } \\
73\end{array}$ & $\begin{array}{c}\text { per cent } \\
111\end{array}$ & $\begin{array}{c}\text { per cent } \\
114\end{array}$ & $\begin{array}{c}\text { per cent } \\
89\end{array}$ & $\begin{array}{c}\text { per cent } \\
87\end{array}$ & $\begin{array}{c}\text { per cent } \\
99\end{array}$ & $\begin{array}{c}\text { per cent } \\
99\end{array}$ & $\begin{array}{c}m m . ~ H g . \\
40.6\end{array}$ & $\begin{array}{c}m m . H g . \\
28.2\end{array}$ & $\begin{array}{c}\text { mm. } \mathrm{Hg} . \\
23.4\end{array}$ \\
\hline M.H. & 67 & 84 & 93 & 106 & 107 & 88 & 99 & 38.7 & 25.0 & 25.1 \\
\hline M.B. & 62 & 110 & 108 & 93 & 96 & 103 & 105 & 38.2 & 27.4 & 22.8 \\
\hline $\begin{array}{ll}\text { J.H. (a) } & \text { (b) }\end{array}$ & 64 & $\begin{array}{r}98 \\
100\end{array}$ & 108 & $\begin{array}{l}76 \\
74\end{array}$ & 86 & $\begin{array}{l}74 \\
73\end{array}$ & 92 & 46.3 & $\begin{array}{l}25.7 \\
24.9\end{array}$ & \\
\hline H.R. (a) & 78 & $\begin{array}{l}97 \\
90\end{array}$ & 100 & $\begin{array}{l}83 \\
96\end{array}$ & 93 & $\begin{array}{l}81 \\
85\end{array}$ & 93 & 42.9 & $\begin{array}{l}28.7 \\
28.5\end{array}$ & 30.0 \\
\hline B & 72 & $\begin{array}{l}88 \\
89\end{array}$ & 81 & $\begin{array}{l}98 \\
93\end{array}$ & 115 & $\begin{array}{l}84 \\
82\end{array}$ & 92 & 36.5 & $\begin{array}{l}32.7 \\
34.0\end{array}$ & 29.8 \\
\hline Average & 69 & 96 & 101 & 90 & 97 & 85 & 97 & 40.6 & 28.4 & 26.2 \\
\hline
\end{tabular}

The peak pulmonary pressure on the pneumolator was 20 to $25 \mathrm{~cm} . \mathrm{H}_{2} \mathrm{O}$. All values in percentage of normal unless otherwise indicated.

volume did not increase in the inflated position in spite of the decreased heart rate. The changes in the heart rate indicate some reflex cardiac effects resulting from different degrees of inflation. This does not help to explain the effects of continuous and intermittent pressure on the heart rate, because the mean lung volume was greater with the former where the heart rate was highest.

\section{(3) Effect of decreased alveolar carbon dioxide tension}

It has been shown that for the same mean pulmonary pressure the cardiac output is more diminished by intermittent than by continuous pressure breathing. This suggests the possibility that the diminished alveolar carbon dioxide tension which accompanies the use of the pneumolator may be responsible for this difference. In order to investigate this hypothesis one of us (M.B.) carried out a series of ballistocardiographic determinations on 6 different subjects in which the effects of voluntary hyperventiliation were compared to the effects of breathing on the pneumolator.

These experiments involved three periods: (1) 10 minutes reclining in the supine position on the ballistocardiograph breathing air normally through an A-13 mask; (2) 10 minutes breathing air through the pneumolator with a peak pressure of
20 to $25 \mathrm{~cm} . \mathrm{H}_{2} \mathrm{O}$; (3) 10 minutes of voluntary hyperventilation. At the close of each period a record was taken on the ballistocardiograph followed by an alveolar air sample taken from a side tube in the mask after a forcible expiration (beginning at the end of expiration).

The results of these measurements are shown in Table III. They indicate that the cardiac output was decreased to 85 per cent of normal by the pneumolator but to only 97 per cent of normal by voluntary hyperventilation. The fall in the alveolar carbon dioxide tension was approximately the same in both cases. Similar results were obtained by Drs. Kety, Schmidt, and Starr, University of Pennsylvania (Personal Communication). The experiments with the pneumolator confirm those reported in Table II. In a second series of experiments air was delivered to the mask through a gas meter which stood in view of the subject. Every 5 seconds the subject inhaled and continued until the pointer had reached a certain point on the dial. In this way the volume of the ventilation could easily be controlled either at 12 or 18 liters per minute. The experiment consisted then of a 10-minute normal period with the mask but without the gas meter, then two 6-minute periods with the gas meter at each of the two increased tidal volumes. Records and alveolar air samples were taken near the end of each period. Three 
experiments were tried on each of 5 subjects. In order to avoid disturbance of the ballistocardiographic record by the mechanical oscillations due to the increased effort of breathing, the subject was instructed to breathe normally while the record was being taken. All records were taken within 30 seconds after the cessation of hyperventilation so that it can be fairly assumed that any effects of lowered alveolar carbon dioxide tension would still be in operation.

The results of these experiments are summarized in Table IV. All the changes are very small

TABLE IV

Effects of voluntary hyperventilation of different degrees on cardiac output. Averages of 3 experiments on each of 5 subjects

\begin{tabular}{|c|c|c|c|c|}
\hline Ventilation & $\underset{\text { reate }}{\text { Heart }}$ & $\begin{array}{l}\text { Stroke } \\
\text { volume }\end{array}$ & $\begin{array}{l}\text { Cardiac } \\
\text { output }\end{array}$ & $\underset{\mathrm{pCO}_{2}}{\text { Alveolar }}$ \\
\hline $\begin{array}{c}\text { liters per min. } \\
\text { Normal } \\
12 \\
18\end{array}$ & $\begin{array}{c}\text { per cent } \\
100 \\
103 \\
103\end{array}$ & $\begin{array}{c}\text { per cent } \\
100 \\
96 \\
92\end{array}$ & $\begin{array}{c}\text { per cent } \\
100 \\
99 \\
95\end{array}$ & $\begin{array}{c}\text { mm. } H_{g} \\
44.1 \\
34.0 \\
24.0\end{array}$ \\
\hline
\end{tabular}

but there is a well marked tendency toward a decreased cardiac output (95 per cent) and a decreased stroke volume (92 per cent) which was not balanced by an increase in heart rate (103 per cent) at the higher rate of ventilation. Intermediate values were obtained at the 12 liter per minute rate. The alveolar $\mathrm{CO}_{2}$ tension at the higher rate was decreased to $24 \mathrm{~mm}$. $\mathrm{Hg}$ which is comparable to the decrease observed in Table III, and the decrease in cardiac output is of the same order of magnitude. The uniformity of the 15 experiments was shown by the fact that at 18 liters per minute 11 experiments showed a decrease in cardiac output, 13 showed a decrease in stroke volume and 13 showed an increase in heart rate or no change. The 5 per cent decrease in cardiac output was statistically significant because the probable error of the mean was only \pm 1.1 (Table IV).

In considering the significance of these results it might be pointed out that increased ventilation requires increased oxygen consumption. Assuming that the cardiac output is increased in proportion to the oxygen consumption, it is possible to predict on the basis of figures for the oxygen consumption in overventilation given by Liljestrand (7), that the cardiac output will be increased 3 per cent at 12 liters per minute and 7 per cent at
18 liters per minute. From these figures it might be argued that if the same ventilation could have been produced passively, so as to avoid the increased cardiac output required for this increased metabolism, the cardiac output would have been only $99-3=96$ per cent at 12 liters per minute, and $95-7=88$ per cent of normal at 18 liters per minute. Such figures actually were closely paralleled by those obtained with the pneumolator where the ventilation was passive although the pressure was elevated.

These results appear to indicate that there is a small but distinct decrease in cardiac output due to diminished alveolar $\mathrm{pCO}_{2}$ but the situation is of course very complicated and the result might be attributed equally well to mechanical effects of the altered respiration. This result also does not permit the conclusion that the decrease in cardiac output observed with the pneumolator is due to the hypocapnia which is produced, because the high pulmonary pressure provides an equally good explanation. In addition, it might be mentioned that Grollman (8) using the acetylene method for cardiac output found an increase with forced ventilation, even when a fall of alveolar $\mathrm{pCO}_{2}$ was prevented by the inspiration of suitable $\mathrm{CO}_{2}$ mixtures. The reason for this discrepancy is not clear.

\section{(4) Experiments with increased dead space}

To complete this study some further measurements were made of the effects of increased alveolar carbon dioxide tensions obtained by increasing the dead space. The subject breathed air through a mask and 3-way cock. The two free ends of the cock were connected to open tubes containing 210 and $760 \mathrm{ml}$. respectively. By turning the cock the subject could be made to breathe in and out through either one of these tubes. Normal records were taken without the mask. Each period was continued for 15 minutes before the record was taken. This experiment was tried on each of 5 subjects. The results were variable and inconsistent. On the average, the addition of either of the two dead spaces increased the cardiac output 2 per cent over the normal value, but this difference was certainly not significant. Other experiments have shown that the alveolar $\mathrm{pCO}_{2}$ was increased in such experiments not more than 0.5 $\mathrm{mm}$. $\mathrm{Hg}$, and $5 \mathrm{~mm}$. $\mathrm{Hg}$ by the 210 and $760 \mathrm{ml}$. dead spaces respectively. 
This experiment indicates that an increase of alveolar $\mathrm{CO}_{2}$ does not increase the cardiac output, and this is consistent with the conclusions reached by Grollman (8) on the basis of the acetylene method. Indeed, if allowance is made for the increased metabolic rate which must have accompanied the increased breathing needed for these dead spaces (about 18 liters per minute with 760 ml.) the effect of the alveolar change by itself might well have been a decrease in the cardiac output.

\section{(5) Effects of oxygen inhalation}

Before considering the ballistocardiographic data, mention should be made of a series of experiments in which the minute volume of the ventilation was measured in three successive periods on air, then pure oxygen, and finally on air. Our purpose was to investigate some of the rather large increases of ventilation produced by oxygen breathing which had been reported, averaging 20 per cent according to Edelmann, Whitehorn, and Hitchcock (9) and 13.4 per cent according to Shock and Soley (10). All our subjects came early in the morning without breakfast and reclined for 30 minutes on a bed before the experiment began. Air or oxygen was inhaled from a spirometer through a mouth piece and valves. Each period lasted for 30 minutes and was followed by a 10-minute rest period. Ventilation was determined from the spirometer which had a capacity of 2 liters per cm. with a total of about 100 liters. In some of the experiments it was the expired air which was collected in a spirometer and measured. Results were corrected to body temperature, pressure and saturation (BTPS). Table V gives the results of 16 experiments on 6 different subjects. In the last two columns the ventilation on oxygen is expressed in percentage of the two control ventilations on air. On the average it is seen that oxygen increases the ventilation $5 \pm 1.2$ per cent compared to the first control, and $6 \pm 0.89$ per cent compared to the second control period. The standard deviations of the mean indicate a very high degree of statistical validity. It is concluded that oxygen increases the minute volume of the ventilation only 5 or 6 per cent, few if any of our figures being as high as those reported previously.

In 10 of the experiments ( 5 subjects) listed in Table $\mathrm{V}$ simultaneous measurements were made
TABLE V

The volume of the ventilation in liters per minute breathing oxygen and air

\begin{tabular}{|c|c|c|c|c|c|}
\hline \multirow{3}{*}{$\begin{array}{l}\text { Subject } \\
\text { HR } \\
\text { HR } \\
\text { HR }\end{array}$} & \multirow{3}{*}{ 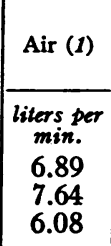 } & \multirow{3}{*}{ 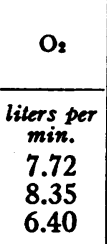 } & \multirow{3}{*}{ 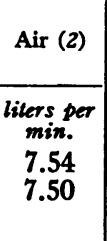 } & \multicolumn{2}{|c|}{$\begin{array}{c}\text { Ventilation in } \mathrm{O}_{2} \\
\text { in percentage } \\
\text { of air }\end{array}$} \\
\hline & & & & (1) & (2) \\
\hline & & & & $\begin{array}{l}112 \\
109 \\
105\end{array}$ & $\begin{array}{l}102 \\
111\end{array}$ \\
\hline $\begin{array}{l}\text { J.H. } \\
\text { J.H. }\end{array}$ & $\begin{array}{l}6.74 \\
6.40\end{array}$ & $\begin{array}{l}7.15 \\
6.54\end{array}$ & $\begin{array}{l}6.45 \\
6.50\end{array}$ & $\begin{array}{l}106 \\
102\end{array}$ & $\begin{array}{l}111 \\
101\end{array}$ \\
\hline $\begin{array}{l}\text { H.M. } \\
\text { H.M. } \\
\text { H.M. }\end{array}$ & $\begin{array}{l}5.46 \\
5.48 \\
5.60\end{array}$ & $\begin{array}{l}5.54 \\
5.76 \\
6.18\end{array}$ & $\begin{array}{l}5.28 \\
6.11 \\
5.81\end{array}$ & $\begin{array}{l}101 \\
105 \\
110\end{array}$ & $\begin{array}{r}105 \\
94 \\
106\end{array}$ \\
\hline $\begin{array}{l}\text { A.C. } \\
\text { A.C. } \\
\text { A.C. } \\
\text { A.C. }\end{array}$ & $\begin{array}{l}6.86 \\
8.05 \\
7.85 \\
6.29\end{array}$ & $\begin{array}{l}7.27 \\
7.66 \\
7.99 \\
6.83\end{array}$ & $\begin{array}{l}7.14 \\
7.06 \\
7.20 \\
6.77\end{array}$ & $\begin{array}{r}106 \\
95 \\
102 \\
108\end{array}$ & $\begin{array}{l}102 \\
108 \\
111 \\
101\end{array}$ \\
\hline $\begin{array}{l}\mathrm{H} \\
\mathbf{H} \\
\mathrm{H} \\
\text { J.H. }\end{array}$ & $\begin{array}{l}6.16 \\
7.09 \\
6.76 \\
5.35\end{array}$ & $\begin{array}{l}7.05 \\
7.50 \\
7.00 \\
5.43\end{array}$ & $\begin{array}{l}6.32 \\
6.67 \\
7.08 \\
4.77\end{array}$ & $\begin{array}{l}114 \\
106 \\
104 \\
101\end{array}$ & $\begin{array}{r}111 \\
112 \\
99 \\
114\end{array}$ \\
\hline $\begin{array}{l}\text { Average } \\
\text { St. dev. } \\
\text { St. dev. of } \\
\text { mean. }\end{array}$ & $\begin{array}{l}6.55 \\
\pm .85 \\
\pm .21\end{array}$ & $\begin{array}{l}6.90 \\
\pm .87 \\
\pm .22\end{array}$ & $\begin{array}{l}6.53 \\
\pm .79 \\
\pm .20\end{array}$ & $\begin{array}{l}105 \\
\pm 4.7 \\
\pm 1.2\end{array}$ & $\begin{array}{l}106 \\
\pm 3.4 \\
\pm .89\end{array}$ \\
\hline
\end{tabular}

of the stroke volume and heart rate with the ballistocardiograph. The results are summarized in Table VI. As before, the values during the oxygen period are calculated in percentage of the two control periods. The fact that these two sets of control values agree so closely shows that no progressive change was occurring in the condition of the subject. The figures show a decrease in the cardiac output during oxygen breathing in every case, averaging 8.5 per cent with a standard deviation of the mean of 1 per cent. Since the stroke volume showed on the average no change, it must be concluded that the decrease in the heart rate was responsible for the decrease in cardiac output. These results agree with those reported by Whitehorn, Edelman, and Hitchcock (11), except that they found a slightly larger decrease in cardiac output amounting to 12 per cent and found the stroke volume decreased as well as the heart rate.

\section{DISCUSSION}

The main question relative to these experiments is whether our procedure has actually measured the cardiac output. In this respect it is satisfying to 
TABLE VI

Effects of oxygen inhalation on cardiac output, heart rate and stroke volume

\begin{tabular}{|c|c|c|c|c|c|c|}
\hline \multirow{2}{*}{ Subject } & \multicolumn{3}{|c|}{$\begin{array}{l}\text { Compared to first } \\
\text { control period }\end{array}$} & \multicolumn{3}{|c|}{$\begin{array}{l}\text { Compared to second } \\
\text { control period }\end{array}$} \\
\hline & $\begin{array}{l}\text { Heart } \\
\text { rate }\end{array}$ & $\begin{array}{l}\text { Stroke } \\
\text { volume }\end{array}$ & $\begin{array}{l}\text { Cardiac } \\
\text { output }\end{array}$ & $\begin{array}{l}\text { Heart } \\
\text { rate }\end{array}$ & $\begin{array}{l}\text { Stroke } \\
\text { volume }\end{array}$ & $\begin{array}{l}\text { Cardiac } \\
\text { output }\end{array}$ \\
\hline & $\begin{array}{l}\text { per } \\
\text { cent }\end{array}$ & $\begin{array}{l}\text { per } \\
\text { cent }\end{array}$ & $\begin{array}{l}\text { per } \\
\text { cent }\end{array}$ & $\begin{array}{c}\text { per } \\
\text { cent }\end{array}$ & $\begin{array}{l}\text { per } \\
\text { cent }\end{array}$ & $\begin{array}{l}\text { per } \\
\text { cent }\end{array}$ \\
\hline $\begin{array}{l}\text { H.R. } \\
\text { H.R. }\end{array}$ & $\begin{array}{l}83 \\
83\end{array}$ & $\begin{array}{l}106 \\
108\end{array}$ & $\begin{array}{l}88 \\
90\end{array}$ & $\begin{array}{l}96 \\
93\end{array}$ & $\begin{array}{r}97 \\
100\end{array}$ & $\begin{array}{l}93 \\
94\end{array}$ \\
\hline $\begin{array}{l}\text { J.H. } \\
\text { J.H. }\end{array}$ & $\begin{array}{l}95 \\
90\end{array}$ & $\begin{array}{r}101 \\
98\end{array}$ & $\begin{array}{l}94 \\
87\end{array}$ & $\begin{array}{l}95 \\
96\end{array}$ & $\begin{array}{r}102 \\
94\end{array}$ & $\begin{array}{l}96 \\
91\end{array}$ \\
\hline $\begin{array}{l}\text { T.H. } \\
\text { T.H. }\end{array}$ & $\begin{array}{l}87 \\
93\end{array}$ & $\begin{array}{r}104 \\
96\end{array}$ & $\begin{array}{l}90 \\
89\end{array}$ & $\begin{array}{l}94 \\
90\end{array}$ & $\begin{array}{r}99 \\
110\end{array}$ & $\begin{array}{l}93 \\
96\end{array}$ \\
\hline $\begin{array}{l}\text { A.C. } \\
\text { A.C. }\end{array}$ & $\begin{array}{r}94 \\
100\end{array}$ & $\begin{array}{l}97 \\
92\end{array}$ & $\begin{array}{l}92 \\
92\end{array}$ & $\begin{array}{l}83 \\
84\end{array}$ & $\begin{array}{l}105 \\
101\end{array}$ & $\begin{array}{l}87 \\
85\end{array}$ \\
\hline $\begin{array}{l}\text { H.M. } \\
\text { H.M. }\end{array}$ & $\begin{array}{l}92 \\
97\end{array}$ & $\begin{array}{r}100 \\
96\end{array}$ & $\begin{array}{l}93 \\
93\end{array}$ & $\begin{array}{l}91 \\
99\end{array}$ & $\begin{array}{r}101 \\
97\end{array}$ & $\begin{array}{l}92 \\
95\end{array}$ \\
\hline $\begin{array}{l}\text { Mean } \\
\text { Stand. dev. } \\
\text { Std. dev. of } \\
\text { mean }\end{array}$ & $\begin{array}{r}91.4 \\
5.6 \\
1.8\end{array}$ & $\begin{array}{r}99.8 \\
5.3 \\
1.7\end{array}$ & $\begin{array}{r}90.8 \\
2.4 \\
0.7\end{array}$ & $\begin{array}{r}92.1 \\
5.2 \\
1.7\end{array}$ & $\begin{array}{r}100.6 \\
4.5 \\
1.4\end{array}$ & $\begin{array}{r}92.2 \\
3.7 \\
1.2\end{array}$ \\
\hline
\end{tabular}

Values in percentage of control periods on air taken before and after the oxygen period.

find that in our trained subjects using continuous pressure breathing, and in all our subjects using intermittent pressure breathing, the cardiac output appeared to be reduced in proportion to the mean pulmonary pressure. This is in agreement with the results reported by Richards (5), with the direct Fick method. We have no similar confirmation of our results with forced breathing where a slight decrease in cardiac output also was found. This is contradictory to the results reported by Grollman (8) with the acetylene method, but may nevertheless be correct for our experimental conditions. There are so many conflicting chemical and mechanical factors involved in forced breathing that either result might be expected according to the exact pattern of the breathing.

The respiratory and circulatory effects of substituting pure oxygen for air are more uniform and indicate a 5 per cent increase in the minute volume of the ventilation and an 8 per cent decrease in the heart rate and cardiac output. Speculation concerning the mechanism of these effects seems futile because of the many possibilities which present themselves. However, it might be pointed out that the initial stimulus presumably depends upon the increased $\mathrm{pO}_{2}$ in the arterial blood. Because of the decreased cardiac output, as well as the increased rate of oxygen consumption reported by Behnke, et al. (12), the mean $\mathrm{pO}_{2}$ in the tissues would not be expected to change very much. The result, however, may depend more upon the response of the cerebral circulation to pure oxygen, and this may be quite different from the average for the whole body.

\section{SUMMARY}

(1) Records were taken with a ballistocardiograph to show the effects on the circulation of variations in intrapulmonary pressure or alveolar carbon dioxide tension, and of pure oxygen inhalation in place of air. The results are interpreted tentatively in terms of cardiac output.

(2) Breathing against a continuously elevated pulmonary pressure decreases the stroke volume but increases the heart rate. Compensation may or may not be complete.

(3) Breathing against a pulmonary pressure which is elevated only during inspiration decreases the stroke volume, in proportion to the mean pulmonary pressure, as well as the heart rate, so that the cardiac output is decreased to 85 per cent of normal.

(4) In voluntary hyperventilation of approximately the same volume as in (3) the cardiac output is diminished to 95 per cent of normal, the stroke volume being decreased and the heart rate increased.

(5) An increase in the dead space caused no consistent effect on cardiac output.

(6) Substitution of pure oxygen for air in normal breathing resulted in an increase of 5 per cent in the volume of the ventilation and a decrease of 8.5 per cent in the heart rate and cardiac output.

\section{BIBLIOGRAPHY}

1. Hamilton, W. F., Notes on the development of the physiology of cardiac output. Fed. Proc., 1945, 4, 183.

2. Starr, I., Rawson, A. J., Schroeder, H. A., and Joseph, N. R., Studies on the estimation of cardiac output in man, and of abnormalities in cardiac function, from the heart's recoil and the blood's impacts; the ballistocardiogram. Am. J. Physiol., 1939, 127, 1.

3. Flack, M., Tests for flying efficiency and flying strain. Med. Res. Council, Special Report, 1920, 53, 93. 
4. Bürger, M., Die Herzstromkurve unter der Einwirkung intrapulmonaler Drucksteigerung. Das Elektrokardiogramm beim Valsalvaschen Versuch. Ztschr. f. d. ges. exper. Med., 1926, 52, 321.

5. Richards, D. W., Jr., Cardiac output by the catheterization technique in various clinical conditions. Fed. Proc., 1945, 4, 215.

6. Lewis, J. J., Lewis, A. E., and Hall, V. E., Influence of respiratory inspiration on heart rate. Proc. Soc. Exp. Biol. and Med., 1943, 52, 52.

7. Liljestrand, G., Untersuchungen über die Atmungsarbeit. Skandinav. Arch. f. Physiol., 1918, 35, 199.

8. Grollman, A., Physiological variations in the cardiac output of man. IX. The effect of breathing carbon dioxide and of voluntary forced ventilation on the cardiac output of man. Am. J. Physiol., 1930, 94, 287.

9. Edelman, A., Whitehorn, W. V., and Hitchcock, F. A., The effect of breathing 100 per cent oxygen on ventilation volume and alveolar $\mathrm{CO}_{2}$ tension. Fed. Proc., 1945, 4, 18.

10. Shock, N. W., and Soley, M. H., Effect of breathing pure oxygen on the respiratory volume in humans. Proc. Soc. Exp. Biol. and Med., 1940, 44, 418.

11. Whitehorn, W. V., Edelman, A., and Hitchcock, F. A., The effect of inhalation of 100 per cent oxygen on cardiac output in man. Fed. Proc., 1945, 4, 76.

12. Behnke, A. R., Johnson, F. S., Poppen, J. R., and Motley, E. P., The effect of oxygen on man at pressures from 1 to 4 atmospheres. Am. J. Physiol., $1935,110,565$. 